\title{
RETHINKING LE CORBUSIER: URBAN DESIGN AND HISTORY
}

\section{MARTA SEQUEIRA}

It is generally assumed that Le Corbusier's urban planning made a break with the past, and that the public spaces designed by him had nothing to do with any thing that existed before - a conviction fostered by both the innovative character of his proposals and by the proliferation in his manifestos of watchwords that mask any evocation of the past - words like civilisation machiniste, l'esprit nouveau, l'architecture de demain. However, in his writings, Le Corbusier often mentioned the powerful analogy that exists between the architecture of other times and the logic of modern production. Vers une architecture, for example, contains a mixture of photographs showing silos, cars, aeroplanes, ships (i.e. the fruits of $19^{\text {th }}$ and $20^{\text {th }}$ century civil architecture and mechanical engineering) alongside photographs of Greek and Roman buildings. While Le Corbusier, at the end of the 1920s, claimed "I have only one teacher: the past; only one education: the study of the past", a series of sketches in the first volume of the Euvre complète, done during his youth at the archaeological sites visited during his Grand Tour, shows that his interest in the past went far beyond a simple reference.

Although various authors have demonstrated the relationship existing between Le Corbusier's singular architectural works and certain buildings of the past that he had known, such connections have rarely been made with respect to public spaces. This special issue of the Journal of Architecture and Urbanism aims to fill that gap by systematically analysing Le Corbusier's relationship with the history of urbanism.

The main thrust of this issue is announced in the title, which is, in itself, a declaration of principles. In rethinking Le Corbusier, we are being urged to free ourselves f rom the complex of preconceived ideas upon which our notion of modernity rests in order to create a broad platform for an extended discussion about Corbusier's urban design and its relationship with history.
Though apparently quite circumscribed, the subject attracted an exceptional response from the international scientific community. Forty proposals were received from the most diverse countries (Portugal, Spain, Italy, Switzerland, England, Scotland, United States of America, Brazil, Argentina, Colombia, Israel, South Africa, Australia and Malaysia) by authors who included both big names from Corbusian studies and young researchers. Of those, nineteen were selected to peer review by independent, anonymous expert referees - nine of which are published in this special issue of the Journal of Architecture and Urbanism, while other selected and positively reviewed articles will appear in forthcoming issues in special sections dedicated to the same subject.

This is, therefore, much more than a mere compilation of texts about Corbusian architecture. The articles gathered here focus on Le Corbusier's reflections about the public space of earlier times and its influence upon his own output, the relationship of his designs with the pre-existing city, and other subjects drawn from all periods of his career and training that clarify the affinity that he established with the past through urban design. They are very heterogeneous, pointing off in different directions and marking the most diverse interests. But at the same time they are interconnected, in that they seek to shed light on the affinity that Le Corbusier established with the past from the point of view of urban design, and open up new perspectives about the public space in his work and its controversial relationship with history. This special issue thus bears witness once again to Le Corbusier's inexhaustible legacy, but also to the usefulness of research on his work and thought - a subject about which it seemed that everything had already been said when, paradoxically, we now know that there is still almost everything left to say. 